\title{
NMR assignment of the C-terminal actin-binding domain of talin
}

\author{
Benjamin T. Goult · Alexandre R. Gingras · Neil Bate · Gordon C. K. Roberts • \\ David R. Critchley · Igor L. Barsukov
}

Received: 26 September 2007/ Accepted: 11 December 2007/Published online: 22 December 2007

(C) Springer Science+Business Media B.V. 2007

\begin{abstract}
Talin is a large dimeric $270 \mathrm{kDa}$ adapter protein which binds the cytoplasmic face of a subset of integrin $\beta$-subunits and couples them to the actin cytoskeleton. Here we report the near complete ${ }^{15} \mathrm{~N},{ }^{13} \mathrm{C}$ and ${ }^{1} \mathrm{H}$ chemical shift assignments for the $\mathrm{C}$-terminal actin-binding domain.
\end{abstract}

Keywords Talin · Integrin · Actin ·

Cell-matrix adhesion $\cdot$ Actin binding domain

\section{Biological context}

Cellular interactions with the extracellular matrix are modulated via dynamic protein complexes associated with the cytoplasmic face of the integrin family of cell adhesion molecules. Talin is one of a number of cytoskeletal proteins including $\alpha$-actinin, filamin, tensin and ILK implicated in linking members of the integrin family of $\alpha \beta$-heterodimeric cell adhesion molecules to F-actin (see Critchley 2000 for review). It is large (2541 amino acids) elongated (50-60 nm) protein composed of a globular head (residues 1-400) containing a FERM domain linked to a flexible rod (residues 482-2541) by a short linker sequence. The FERM F3 subdomain contains a binding site for the $\beta$-integrin cytoplasmic domain, and recent structural studies have provided a detailed understanding of how F3 recognises both the

B. T. Goult · A. R. Gingras · N. Bate .

G. C. K. Roberts - D. R. Critchley

Department of Biochemistry, University of Leicester,

Lancaster Road, Leicester LE1 9HN, UK

\section{L. Barsukov ( $\square)$}

School of Biological Sciences, University of Liverpool,

Crown Street, Liverpool L69 7ZB, UK

e-mail: igb2@liv.ac.uk
$\mathrm{NP} \times \mathrm{Y}$ motif and membrane proximal sequences within the $\beta$-integrin cytodomain (Wegener et al. 2007). The talin rod is made up of a series of amphipathic helical bundles, a number of which contain binding sites for the cytoskeletal protein vinculin which is thought to stabilise focal adhesions, possibly by cross-linking talin to F-actin. The C-terminal region of talin (residues 2300-2541) contains the major binding site for F-actin (Hemmings et al. 1996) that is homologous to that in the yeast protein Slap2 and the Huntingtin interacting protein HIP1, and the related protein Hip1R. This highly conserved domain has been referred to as an I/LWEQ motif (McCann and Craig 1997) or more recently the THATCH (talin-Hip1/R/Sla2p actin tethering C-terminal homology) core domain (Brett et al. 2006).

\section{Methods and experiments}

Multiple polypeptides corresponding to different C-terminal fragments of talin were made and expressed in E. coli BL21 Star (DE3) cultured in M9 minimal media, using ${ }^{15} \mathrm{~N}$-ammonium chloride. The recombinant His-tagged protein was purified by nickel-affinity chromatography and eluted by an imidazole gradient. The His-tag was removed by cleavage with TEV protease prior to further purification by anion-exchange chromatography. NMR samples of $\left[{ }^{15} \mathrm{~N},{ }^{13} \mathrm{C}\right]$-labeled C-terminal actin-binding domain were prepared at $1 \mathrm{mM}$ in $20 \mathrm{mM}$ sodium phosphate, $50 \mathrm{mM}$ $\mathrm{NaCl}, 2 \mathrm{mM}$ DTT, pH 6.0 and $10 \% \mathrm{v} / \mathrm{v} \mathrm{D}_{2} \mathrm{O}$.

Comparison of the NMR spectra of the different $\mathrm{C}$-terminal fragments of talin that contain the actin binding domain led to identification of a minimal region (residues 2300-2482) that incorporates the complete domain. Extension of the sequence at the $\mathrm{N}$ - or C-terminus added unstructured regions to the protein, while truncation 


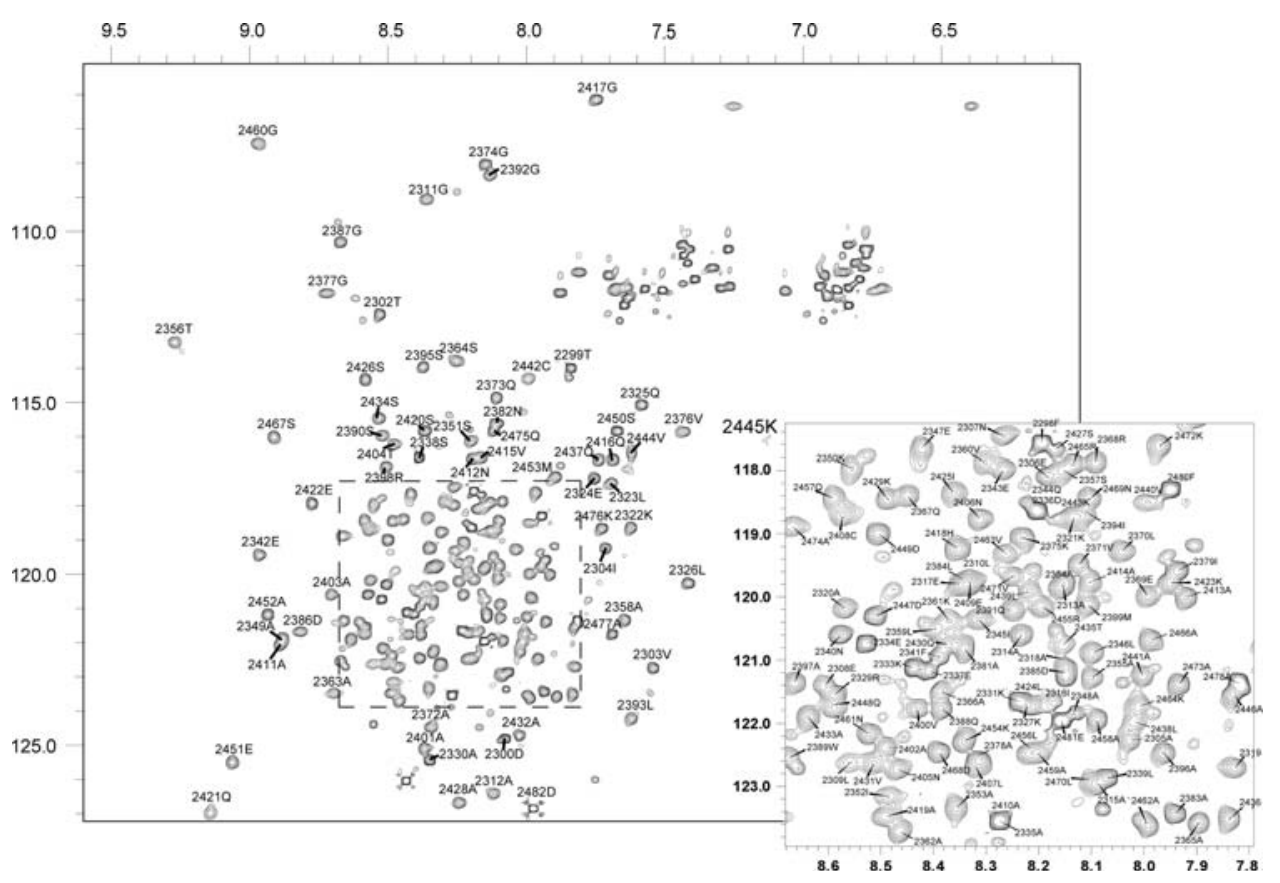

Fig 1 Assigned $\left[{ }^{1} \mathrm{H},{ }^{15} \mathrm{~N}\right]-\mathrm{HSQC}$ spectrum of the talin C-terminal actin-binding domain, residues $2300-2482, T=318 \mathrm{~K}$. Inset: A zoomed in view of the central region

resulted in a partially folded domain. NMR and CD analysis demonstrated exceptionally high thermal stability of the domain with the melting temperature of $\sim 90^{\circ} \mathrm{C}$. This construct was then expressed and purified as before, but in M9 (minimal media, using ${ }^{15} \mathrm{~N}$-ammonium chloride and ${ }^{13} \mathrm{C}$-glucose.

NMR experiments were performed on a Bruker AVANCE DRX 600 spectrometer and an AVANCE DRX 800 equipped with CryoProbes. Due to the high thermal stability of the domain it was possible to use elevated temperatures and the experiments described here were all performed at $45^{\circ} \mathrm{C}$. Proton chemical shifts were referenced to external DSS. The ${ }^{15} \mathrm{~N}$ and ${ }^{13} \mathrm{C}$ chemical shifts were referenced indirectly using recommended gyromagnetic ratios (Wishart et al. 1995). Spectra were processed with TopSpin (Bruker) and analysed using CCPN Analysis (Vranken et al. 2005). 3D HNCO, HN(CA)CO, HNCA, $\mathrm{HN}(\mathrm{CO}) \mathrm{CA}, \mathrm{HNCACB}$ and $\mathrm{HN}(\mathrm{CO}) \mathrm{CACB}$ experiments were used for the sequential assignment of the backbone $\mathrm{NH}, \mathrm{N}, \mathrm{CO}, \mathrm{C} \alpha$ and $\mathrm{C} \beta$ resonances. Side chain assignments were obtained using 3D $\operatorname{HBHA}(\mathrm{CO}) \mathrm{NH}$, HBHANH, $\mathrm{H}(\mathrm{C}) \mathrm{CH}-\mathrm{TOCSY}$ and (H)CCH-TOCSY experiments. Aromatic side chain assignments were obtained using ${ }^{13} \mathrm{C}$-resolved 3D NOESY-HSQC.

Resonance assignment reported here and secondary structure analysis show that the actin-binding domain is composed of five helices of 22-33 residues long (regions T2302-Q2325， F2341-Q2373， A2383-Q2416， S2420V2444 and E2451-K2476) some which are connected by long unstructured loops.

\section{Extent of assignments and data deposition}

Backbone $\mathrm{HN}, \mathrm{N}, \mathrm{CO}, \mathrm{C} \alpha$ and $\mathrm{C} \beta$ resonances have been completely assigned. Assignments for non-exchangeable protonated side-chain groups are essentially complete (99.9\%) with the exception of serine 2427 where the side chain could not be assigned due to signal overlap. The assigned $\left[{ }^{1} \mathrm{H},{ }^{15} \mathrm{~N}\right]$-HSQC spectrum is shown in Fig. 1 . Resonance assignments have been submitted in the BioMagResBank (http://www.bmrb.wisc.edu/) with the accession number 15411. The assignments of the actin binding domain of talin reported here complement deposited resonance assignments for other talin domains: VBS2 domain from the talin rod (residues 755-889, accession number 6582), a spacer domain from the talin rod (residues 1655-1822, accession number 15457), and F3 subdomain of the talin head (residues 304-405, accession numbers 7061 and 7150).

Acknowledgements The work was supported by a programme grant from the Wellcome Trust and a grant from the NIH Cell Migration Consortium.

\section{References}

Brett TJ, Legendre-Guillemin V, McPherson PS, Fremont DH (2006) Structural definition of the F-actin-binding THATCH domain from HIP1R. Nat Struct Mol Biol 13:121-130

Critchley DR (2000) Focal adhesions-the cytoskeletal connection. Curr Opin Cell Biol 12:133-139 
Hemmings L, Rees DJ, Ohanian V, Bolton SJ, Gilmore AP, Patel B, Priddle H, Trevithick JE, Hynes RO, Critchley DR (1996) Talin contains three actin-binding sites each of which is adjacent to a vinculin-binding site. J Cell Sci 109:2715-2726

McCann RO, Craig SW (1997) The I/LWEQ module: a conserved sequence that signifies $\mathrm{F}$-actin binding in functionally diverse proteins from yeast to mammals. Proc Natl Acad Sci USA 94:5679-5684

Vranken WF, Boucher W, Stevens TJ, Fogh RH, Pajon A, Llinas M, Ulrich EL, Markley JL, Ionides J, Laue ED (2005) The CCPN data model for NMR spectroscopy: development of a software pipeline. Proteins 59:687-696

Wegener KL, Partridge AW, Han J, Pickford AR, Liddington RC, Ginsberg MH, Campbell ID (2007) Structural basis of integrin activation by talin. Cell 128:171-182

Wishart DS, Bigam CG, Yao J, Abildgaard F, Dyson HJ, Oldfield E, Markley JL, Sykes BD (1995) 1H, 13C and 15N chemical shift referencing in biomolecular NMR. J Biomol NMR 6:135-140 